Article

\title{
Local Management System of Dragon's Blood Tree (Dracaena cinnabari Balf. f.) Resin in Firmihin Forest, Socotra Island, Yemen
}

\author{
Abdulraqeb Al-Okaishi ${ }^{1,2}$ \\ 1 Department of Forest Botany, Dendrology and Geobiocoenology, Faculty of Forestry and Wood Technology, \\ Mendel University in Brno, Zemědělská 3, 613-00 Brno, Czech Republic; abdulraqeb07@yahoo.com; \\ Tel.: +967-777-727-748 \\ 2 Environmental Protection Authority, 20 Main Street-P.O. Box 111, Hadibo, Socotra Island, Yemen
}

Received: 16 January 2020; Accepted: 25 March 2020; Published: 1 April 2020

\begin{abstract}
Various nontimber forest products (NTFPs) are produced from the forests and woodlands of Yemen. Dragon's blood tree resin is one of the commercial NTFPs in Yemen and is produced by tapping Dracaena cinnabari trees, which are listed as vulnerable by the IUCN (International Union for Conservation of Nature) Red List. By applying a forest resource assessment, the present study inventoried the D. cinnabari forest with the aim of identifying and evaluating its structure, the harvesting status of the resin, and the current management system. The study was conducted in the Firmihin forest, Socotra Island, Yemen Republic. The forest resource assessment was carried out through a forest inventory by measuring trees from 12 plots following stratified random sampling. The relevant parameters of a total of 819 trees were measured, including the tree height, stem height of lowest branches, height of the highest wound, diameter at breast height (DBH), and presence of wounds. The wounds were measured on a total of 401 trees. Value chain analysis (VCA) was used to clarify the flow of dragon's blood tree resin from the producers to the local, national, and international markets. Traditional management was examined using questionnaires in the case study area and surrounding villages. There are two tapping techniques: (1) collecting the pure dragon's blood tree resin and (2) cutting part of the bark along with the pure resin. The second technique resulted in $84 \%$ of the trees having wounds. The tappers were mostly from the community in and around the forest. The study found that the traditional management system of tapping dragon's blood tree resin is not sustainable.
\end{abstract}

Keywords: tree damage; wounds; harvesting rules; climate change; local community

\section{Introduction}

Up to $80 \%$ of the population in developing countries depend on nontimber forest products (NTFPs) for economic and food subsistence [1]. The link between NTFPs and the objectives of conservation and development has achieved global resonance, especially among forest researchers [2-5]. The harvesting of NTFPs requires serious attention as part of viable rural development alternatives and the sustainable use of tropical forests [1,2]. Resin exudes from a variety of tree species, partly as the result of natural phenomena and partly from injury to the bark or stem of trees. It exudes in liquid form and, upon exposure to air, dries into translucent tears that remain stuck to the bark of the stem or branch, from which they are removed by collectors. People use resin for a variety of purposes: as adhesives, for pharmaceutical uses, for painting, and as food additives [3]. In Yemen, there are many species that provide NTFPs, such as Ziziphus spina-christi, Commiphora spp., Boswellia spp. [4,5], and D. cinnabari [6], and many other species are famous for their products, which are traded and used in local, national, and international markets. Very little is known about harvesting, processing, or marketing of NTFP species. 
The Socotra Archipelago, which is located at the crossroads between the Red Sea, the Arabian Sea, and the Indian Ocean, is recognized as a regional center of biodiversity and was declared a UNESCO World Natural Heritage Site in 2008. The archipelago is rich in biodiversity, with spectacular endemic species; more than $37 \%$ of the plant species are endemic [7], including the dragon's blood tree (D. cinnabari), but The area is also rich in traditions that have conserved this biodiversity until today [6]. D. cinnabari greatly contributes to the biodiversity value of the island [8]. This tree is the island's flagship species [9], and the local Dracaena forest represents one of the Earth's oldest forest ecosystems [10]. It was presumably present over larger areas of the island in the past [11-14]. This vegetation type is unique to Socotra, and as such, it is extremely important and has high global significance [15]. According to Attorre et al. [11], the Firmihin forest could be destroyed within 60 years due to the increasing aridity caused by global climate change forces. Habrová et al. [16], Hubálková [12], and Maděra et al. [9] showed a 40\% decrease in population abundance after 100 years, taking into account only the internal force of aging (assuming little or no regeneration).

Secondary thickening is usually absent in monocot plants, but Dracaena is an anomalous example [17-19]. The tracheid network in the secondary vascular bundles functions both for transport and mechanical support [20-22], and the secondary vascular bundles also serve as stores of carbohydrates and water in aboveground organs [23]. The Dracaena species produce dragon's blood as a defense mechanism [24]. However, the anatomical structure that produces the dragon's blood remains unclear [24,25]; authors have proposed two possible resin origins in the bark [26], xylem [24,27], or living cells [28].

The Dracaena species are characterized by crowns with well-separated rosettes directed upward that allow the captured and redirected water to be intercepted by leaves and transported into the succulent bodies of the tree for storage and future use [29]. Dracaena also have the ability to bypass axial water flow by lateral transport in the case of stem wounding [30]. The vascular bundles of Dracaena species can create a three-dimensional network interconnected by pits and embedded in ground tissues, which gives them the ability to conduct water in any direction [31]. The succulent and xerophytic features that have also been observed in D. cinnabari and D. draco, such as narrow leaves, thick cuticles and high leaf mass per area, indicate their resistance to high transpiration rates [32]; they also appear to have a high density of stomata on both sides of the leaves and stomata surrounded by a cuticular flange [22]. Photosynthesis, metabolism, nitrogen assimilation, and mineral nutrition have been poorly studied to date, and other basic physiological studies still require future intensive research.

Dragon's blood tree resin that is harvested/collected from D. cinnabari is the most important local NTFP. It provides income for the rural population in Socotra and is becoming even more important with the increases in population, unemployment, and tourism activities [33]. Dragon's blood tree resin was a highly prized product of the ancient world, and Roman traders were aware of the dragon's blood trees growing on Socotra. Periplus mentioned [34] that "The island yields no fruit, neither vine nor grain, and there is also produced on this island cinnabar (dragon's blood tree resin), which is collected in drops from the trees"; local people continue to trade and use this substance locally today. Although there is a recognizable market for dragon's blood resin in local, national and international markets, no study on the chain of harvesting, processing and marketing is available.

Currently, the main problem is the large number of trees that have been tapped in the past, and that the continued tapping of these trees occurs in an unsustainable manner [12]. Currently, there is little demand for the resin, but overexploitation will be a future problem with the increase in population, demand, and loss of traditional knowledge and harvesting rules. The almost complete eradication of the closely related D. draco on the Canary Islands has been linked to overexploitation of this species for dragon's blood resin in the Middle Ages [35]. The islanders have harvested dragon's blood resin on Socotra for a long time, using it locally or exporting it outside the island as one of the important products in ancient world trade. However, there is no precise record on the present or past traditional management of the dragon's blood tree forest, and there has been no analysis of whether the existing 
harvesting management system is sustainable (from a conservation perspective) or not. This study describes the resin harvesting system.

\section{Materials and Method}

\subsection{Study Area}

Socotra Island is located between $12^{\circ} 19^{\prime}-12^{\circ} 42^{\prime} \mathrm{N}$ and $53^{\circ} 18^{\prime}-54^{\circ} 32^{\prime} \mathrm{E}$ and is part of the Republic of Yemen, with a total area of $3675 \mathrm{~km}^{2}$. The island is characterized by its high, scenic central mountains, and the Haggeher Mountains peaks, which rise up to $1500 \mathrm{~m}$ at the peak of Skand [36]. The climate is characterized by a southwest monsoon in summer that continues from June to September, bringing hot, dry, strong winds and occasional rainfall into the Haggeher Mountains, while the northeast monsoon in winter (November-January) is less pronounced and coincides with the mainly rainy season in the north. The annual rainfall ranges between $200 \mathrm{~mm}$ in the coastal plains and $1000 \mathrm{~mm}$ in the high mountains [37,38].

The present study was conducted in the Firmihin forest (area: $550 \mathrm{ha}$ ), which is located roughly in the middle of Socotra Island (Figure 1). Firmihin, or Rokeb di Firmihin, is situated on the limestone plateau to the south of the Haggeher Mountains [14]. Its altitude ranges from $350 \mathrm{~m}$ a.s.l. in Soreno village in the south to $780 \mathrm{~m}$ a.s.l. around Terebek village in the north. It was characterized as forest in a recent land-cover map [39]. According to local leaders, approximately 300 people live in the study area in 7 small villages. Some villages have just 2 to 4 houses.

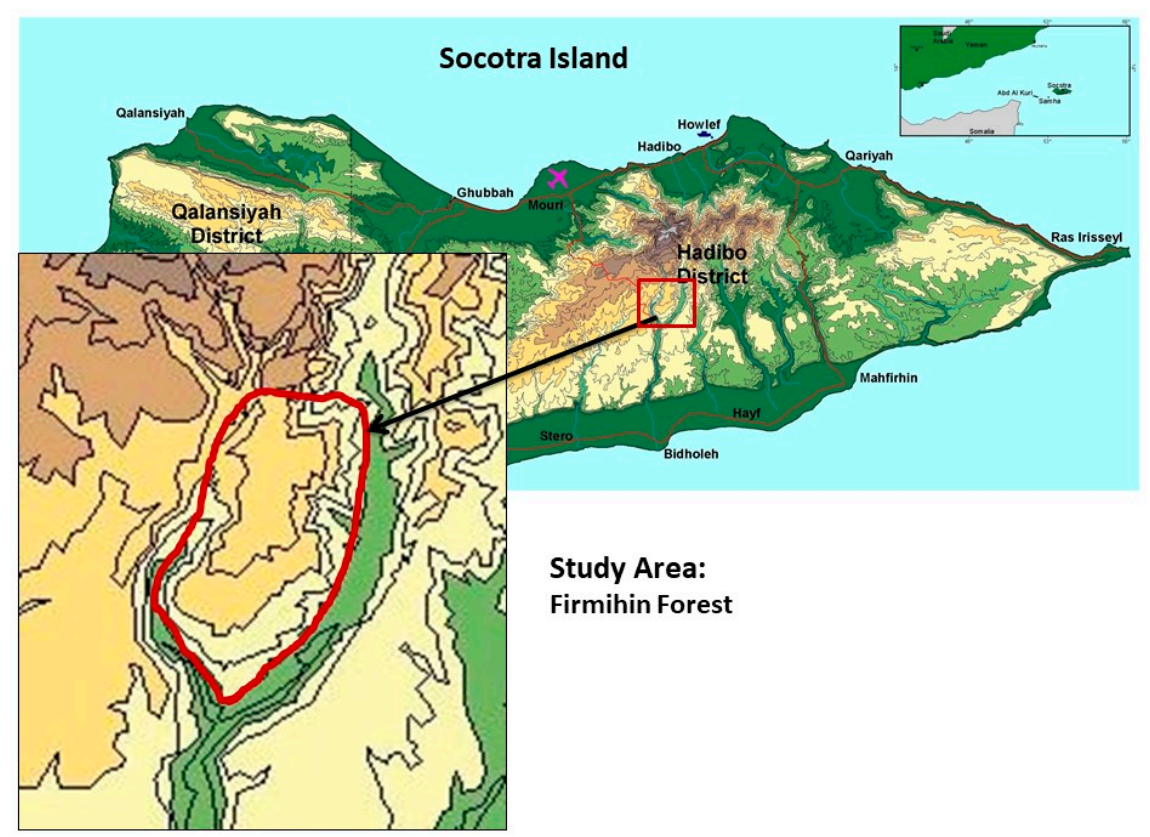

Figure 1. Location of the study area (adapted from master plan EPC (Environment Protection Council), MoPD (Ministry of Planning and Development), and MoHCUP (Ministry of Housing, Construction and Urban Planning) Republic of Yemen).

The local people are pastoralists, spending most of the winter and the summer rainy season in Firmihin along with their livestock and most of the summer dry season in the Haggeher Mountains. Some go farther east with their cows to the Momi area. They do not cultivate date palms, and they have very few home gardens. This locality was selected due to the occurrence of a relatively dense D. cinnabari forest distinguished by high canopy closure (over 30\%) [39]. The area has very clear boundaries formed by deep surrounding wadis (Figure 1). 


\subsection{Data Collection}

In 2010, in the Firmihin forest (study area), 12 plots of $100 \times 100 \mathrm{~m}$ were randomly stratified and selected according to altitude (see Table 1 and Figure 2).

Table 1. Areas stratified according to altitude.

\begin{tabular}{ccc}
\hline Stratified Areas & Altitude & No. of Plots \\
\hline & (m.a.s.l) & (ID) \\
Area 1 & $500-599$ & $9,10,11,12$ \\
Area 2 & $600-699$ & $4,6,8$ \\
Area 3 & $700-799$ & $1,2,3,5,7$ \\
\hline
\end{tabular}

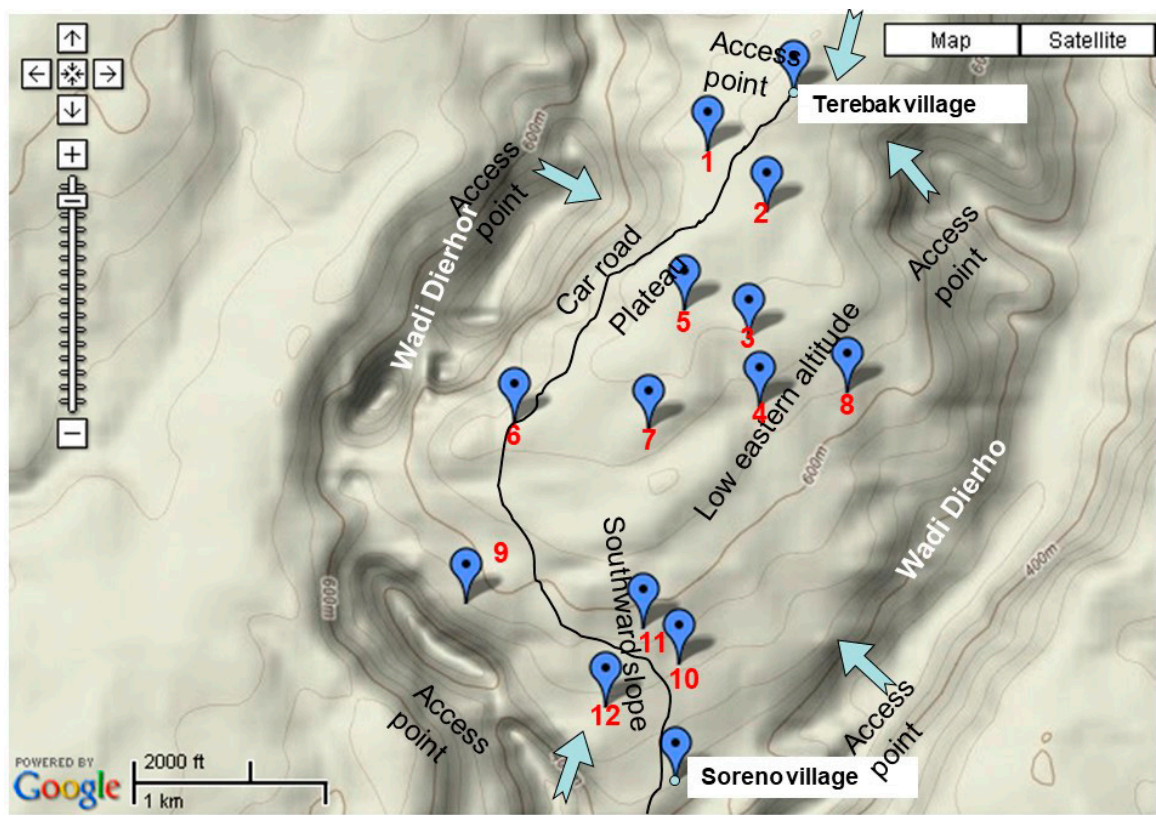

Figure 2. Location of 12 study plots (base map from Google).

The number of trees $(\mathrm{N})$, diameter at breast height of each tree $(\mathrm{DBH})$, height of the trees $(\mathrm{H})$, stem height $(\mathrm{Hb})$, and height of the highest wound $(\mathrm{Hw})$ were measured. Due to time restrictions but while still maintaining the power of the results, the wounds were measured for every second tree. Additionally, the existence of wounds (yes or no), status of tapping (whether the tree was harvested this year or not; identified by white bark) and the status of the crown and trunk were ranked in 5 categories (own classification, see Figures 3 and 4).

The data from stakeholders were mainly gathered through in-depth face-to-face interviews using semistructured questionnaires, which was further strengthened by key informant interviews and direct observations. The in-depth semi-structured interviews were conducted with 63 interviewees to collect data from the tappers of the dragon's blood tree resin, who had harvested from the study area. These interviews were carried out in three communities and included children or youth and women (Table 2). The interview covered basic information about the informant and their livelihood, the time of harvesting and the harvesting area, the harvesting techniques, marketing, income, and local management. Key informant interviews were carried out with community leaders, educated people in the community, and people from the communities who worked with government offices and the Environmental Protection Authority Socotra staff. Key informant interviews were also conducted with the wholesalers or retailers in the local and national markets. 


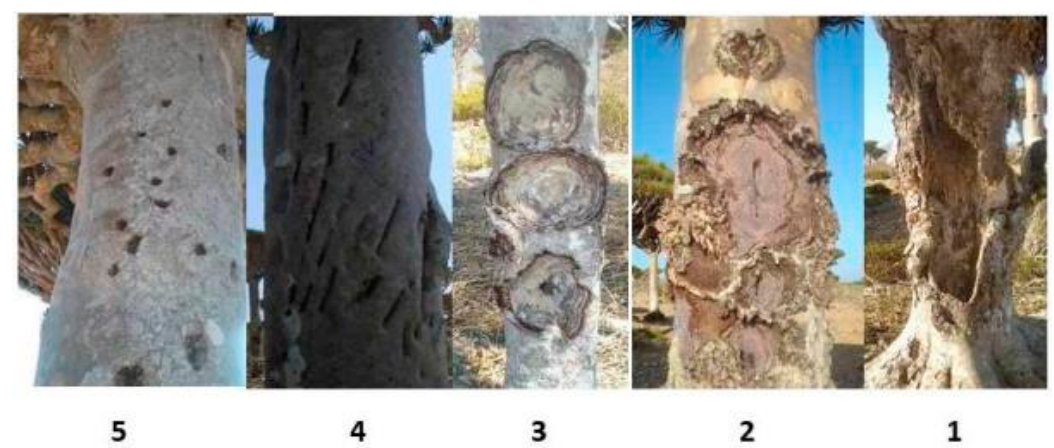

Figure 3. Trunk status categories (own classification). (5): trunk without wounds or with a few small wounds of 2-3 cm diameter or one medium wound of 3-10 cm diameter; (4): trunk with several small wounds or a few medium wounds but The trunk is still strong; (3): trunk with large wounds of 10-40 cm diameter and greater, with the center of the trunk still alive; (2): trunk with large wounds, the center of the wounds mostly dead and sometimes hollow, the wounds sometimes linked together; (1): trunk with large hollow wounds.

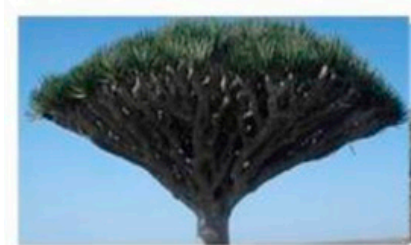

5

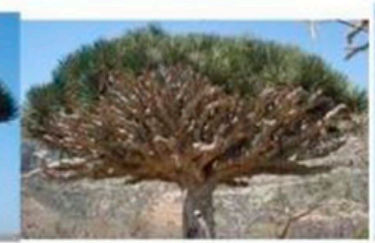

4

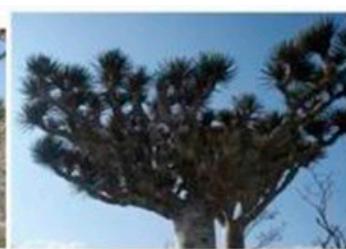

3

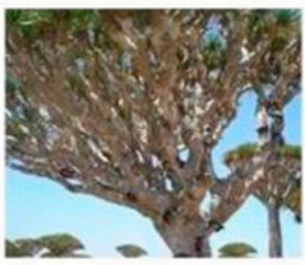

2

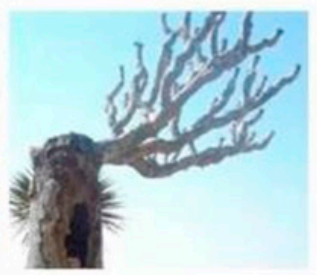

1

Figure 4. Crown status categories (own classification). (5): full crown without any broken branches and with very few small wounds; (4): full crown with some broken branches and wounds; (3): damaged crown with many broken branches and wounds; (2): highly damaged crown with nearly half of the crown affected by many wounds and broken branches and branches with very few leaves; (1): crown with few branches and dead branches but The tree is still alive.

Table 2. The interviews covered different groups of harvesters (in 3 different localities).

\begin{tabular}{ccccc}
\hline Area & Firmihin & Dierho & Shibehon & Total \\
\hline Male & 22 & 11 & 9 & 42 \\
Female & 12 & 3 & 6 & 21 \\
18 years & 10 & 2 & 1 & 13 \\
Total & 34 & 14 & 15 & 63 \\
\hline
\end{tabular}

Secondary data were obtained through a literature review of several documents that discussed NTFPs, D. cinnabari trees, and their resin [1,40-47]. The local management system was assessed using forest resource assessment (FRA) 2000 terminology [48]. To shed light on forest utilization and product marketing, the value chain analysis (VCA) and arena, actors, and institutions (A2I) approach were used to explain the interactions between actors in specific arena and all institutions arrangements that organize these interactions [49-52]. 


\subsection{Data Analysis}

After data collection, all quantitative and qualitative data were entered into Excel worksheets. The quantitative data from the inventory were analyzed using the RStudio program. Histograms, correlations using models (such as the generalized linear mixed model), and multiple comparisons using the least significant difference are good tools for detecting relationships between different variables. The tree density (De) was calculated using the following formula: $\mathrm{De}=\mathrm{N} /$ Area, where $\mathrm{N}$ is the number of trees. Several wound variables were calculated: $\mathrm{Wt}=$ percentage of trees with wounds [\%], $\mathrm{Ut}=$ percentage of trees with used wounds [\%], Aw = percentage of wounded area per tree [\%], and $\mathrm{Nw}=$ average number of wounds per tree $\left[\mathrm{n} \cdot \mathrm{t}^{-1}\right]$.

\section{Results}

\subsection{Firmihin Forest Structure}

The species composition of the Firmihin evergreen forest is largely uniform, and the Dracaena forest covers the entire area. The average density of $D$. cinnabari trees with all trees included is 67 trees ha $^{-1}$. The tree density is not distributed equally; it varies among plots from 19 to 169 trees ha $^{-1}$ (Table 3). Dracaena trees dominate the upper layer, with heights ranging from 2.9 to $8.9 \mathrm{~m}$, and a mean average height of $5.2 \mathrm{~m}$ is associated with some other tree species, such as Boswellia sp. A, Boswellia dioscoridis, Commiphora ornifolia, and Ficus salicifolia.

Table 3. The basic measurement data for 819 trees (from field survey).

\begin{tabular}{cccccc}
\hline Plot No. & Plots Area & $\begin{array}{c}\text { No. of } \\
\text { Living Trees }\end{array}$ & $\begin{array}{c}\text { No. of } \\
\text { Dead Trees }\end{array}$ & Total Trees & $\begin{array}{c}\text { No. of Trees } \\
\text { Measured for Wounds }\end{array}$ \\
\hline (n) & $($ ha) & $(\mathrm{n})$ & $(\mathrm{n})$ & $(\mathrm{n})$ & $(\mathrm{n})$ \\
1 & 1 & 94 & 0 & 94 & 47 \\
2 & 1 & 138 & 5 & 143 & 69 \\
3 & 1 & 40 & 0 & 40 & 20 \\
4 & 1 & 164 & 5 & 169 & 79 \\
5 & 1 & 69 & 4 & 73 & 36 \\
6 & 1 & 28 & 1 & 29 & 14 \\
7 & 1 & 19 & 0 & 19 & 10 \\
8 & 1 & 116 & 2 & 118 & 57 \\
9 & 1 & 19 & 0 & 19 & 10 \\
10 & 1 & 23 & 2 & 25 & 32 \\
11 & 1 & 62 & 3 & 65 & 15 \\
12 & 1 & 19 & 6 & 25 & 401 \\
\hline
\end{tabular}

Most of the trees were close to the average DBH of $37.9 \mathrm{~cm}$, and the diameters had a wide range from 8.0 to $82.3 \mathrm{~cm}$, with standard deviation of the mean (SD 10.9). The curve shows a normal distribution with a $p$-value $=4.009 \times 10^{-7}$ that was obtained by the Shapiro-Wilk normality test.

According to the inventory, there were 28 dead trees in 12 plots (12 ha); through further calculation, it was estimated that there are 1283 dead trees in the whole forest (550 ha). Estimating that those trees died during the past 10 years, we conclude that approximately 129 trees die per year. According to the calculation, 36,300 (trees in 550 ha) divided by 129 tree deaths each year means that the forest may be completely dead within 281 years. This estimation does not include any climatic or overmaturity scenarios that could accelerate this mortality.

\subsection{Dragon's Blood Harvesting}

The measurements and observation showed that $84 \%$ of the living trees had wounds. In addition, 43 people out of 62 respondents said "there are many wounds". Of the wounded trees, only $31 \%$ of the trees were used during this season (Figure 5). 


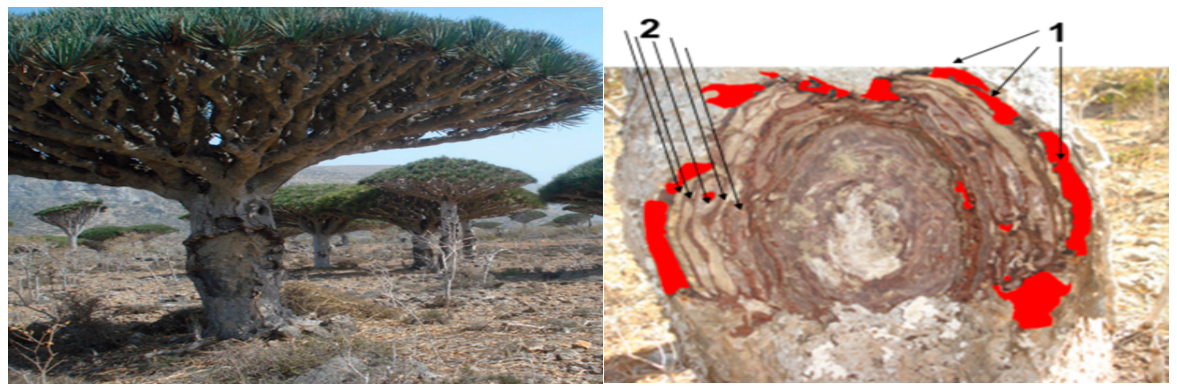

Figure 5. Wounds on the tree and demonstration show harvested wound, present season (red color) (1) and area harvested in previous seasons (2). Own photo.

There were three proposed origins of the D. cinnabari wounds: 19 of 61 respondants said that these wounds occurred naturally through the almighty creator (Allah). In the second case, 20 people out of 61 respondents stated that these wounds were made by people, and nearly half of them thought the wounds were from the past. Only 6 people reported making new wounds but lacked any special knowledge. The dragon's blood tree resin is found on the outer edges of the wound, where it is healing the area that was injured by harvesting (Figure 5).

From 63 questionnaires, responses to the question "who makes decisions about harvesting?", 22 mentioned the sheikh of Firmihin by name, 20 mentioned muqaddams (The village leaders), 12 said "sheikhs" without specification, 12 named other sheikhs in the area, 10 simply said "The people of the area", and 7 did not answer the question. The people gave more than one answer to the question.

The harvesting season is followed by recovery time that lasts from 2 to 5 years. The recovery times suggested by the people ranged between 1.5 to 7 years, with an average of 4.5 years between harvesting seasons. There are four community groups that harvest the Firmihin forest:

1. the community of Firmihin (The Dimeroh community) generally controls the Firmihin forest.

2. the neighboring communities are represented by the Dierho community, which is the closest neighbor and traditionally shares pastures with the Firmihin community. They also share some responsibility in decision-making about dragon's blood tree resin harvesting.

3. the Shibehon community, which has been invited to harvest dragon's blood resin due to neighbor and family relationships.

4. Others, such as the communities of the Haggeher Mountains, Tida'a, Deismo, and Diksam, hear about the opening of the harvesting season or are invited by their friends.

Four materials can be gathered from the tree: (1) pure dried fresh resin, such as a small ball called "Fosoos", (2) broken large and medium slices of resin called "Shahiz", (3) small slices of resin called "Daqa", and (4) bark of the tree derived from harvesting or from dead wood. All pure dragon's blood resin (Fosoos, Shahiz, and Daqa) is called Emselo. All melted or cooked resin is called Edha'a or Matbukh, which means to be cooked. The large "Fosoos" balls can be removed by hand or using the tip of a knife. A knife is used for harvesting Shahiz and Daqa. Part of the bark is cut until the white bark can be seen, which will induce the plant to produce resin to heal the wound. This produces a wound with harvesting rings. Traditionally, a bag made from goat skin was used to collect the product, but currently, they also use plastic bags. Some of the harvesters collect Fosoos and Shahiz first and, after, take parts of the bark separately. Others collect all types together and later separate them into different grades in their homestead. In these mixes, there are very small pieces of "Daqa"; this is mixed with the red bark, and they are cooked together and called Matbukh ("cooked") or Edha'a (mixed resin). The quality of Edha'a depends on the amount of pure resin cooked with the bark.

\subsection{The Impact of Dragon's Blood Harvesting on Trees}

The average height of the highest wound was $1.8 \mathrm{~m}$ (Figure 6), and by taking the standard deviations, 95\% (0.71 SD) of the trees had their highest wounds located lower than $3.2 \mathrm{~m}$. 
As presented in Figure 7, the analysis of variance (ANOVA; $p$-value $<0.05$ ) was run, and the data were tested with the LSD test and visualized, which showed that Treatments 1, 2 and 3 belonged to the same group (all are marked as "a"), and Treatments 4 and 5 were another group, "ab". Therefore, according to the dependent variable (number of wounds), a significantly lower wound number was observed on trees with crown statuses 4 and 5 (which are logically the "best" trees), and a higher wound number was observed on trees with crown statuses 1,2, and 3 (highly damaged). Therefore, the high numbers of wounds caused low vitality of the tree, and the low number of trees in with crown status 1 (highly damaged) additionally showed that the highly damaged trees were more likely to be removed by natural factors, such as the strong monsoon wind on Socotra.

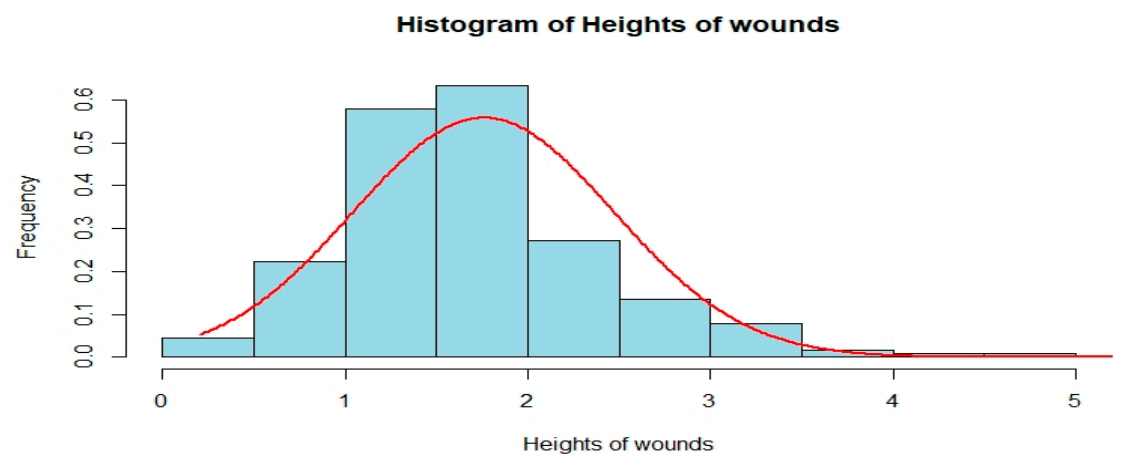

Figure 6. Height to wound distribution frequency showing that $95 \%$ of the trees had wounds located lower than $3.2 \mathrm{~m}\left(p\right.$-value $=3.154 \times 10^{-15}$; field measurements $)$.

Groups and Range

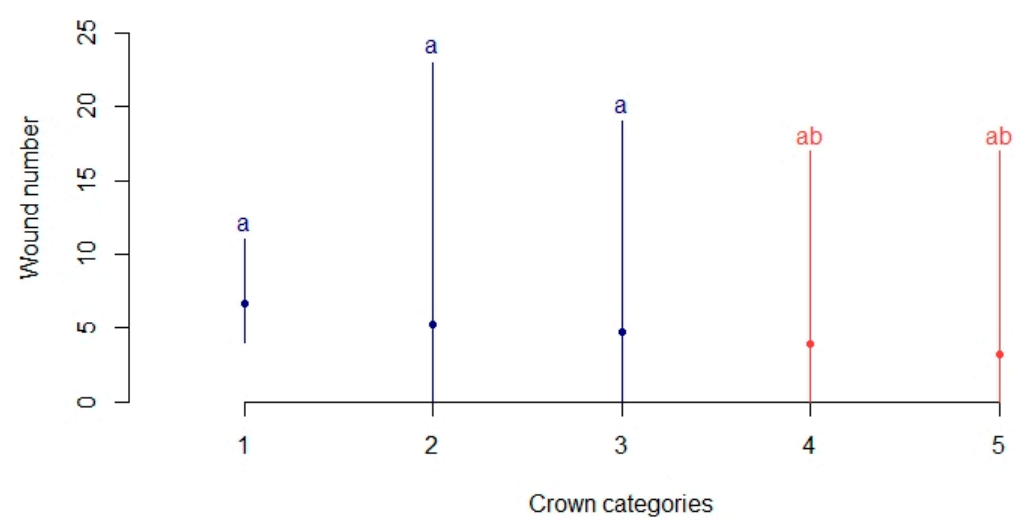

Figure 7. Correlation showing the relationship between the crown categories and wound number; two groups were identified: A and ab ( $p$-value $=0.0004154$ ).

The contingency table (barplot) in Figure 8 shows that the frequency of trees with damaged crowns was positively associated with the frequency of trees with damaged trunks according to the chi-square test $(p$-value $<0.05)$, suggesting that due to harvesting (wounds), the trunk becomes damaged, and the whole tree becomes weak.

\subsection{Value Chain Analysis}

From the inventory, $84 \%$ of trees were wounded, and the community recently (during this harvesting season, which occurred 4 months before the study period) harvested only $31 \%$ of the trees. According to the questionnaires, every person seasonally collected an average of $47.55 \mathrm{~kg}$ Edha'a and $6.40 \mathrm{~kg}$ Emselo (pure dragon's blood resin). These amounts were gathered seasonally, with an average of $0.54 \mathrm{~kg}$ Edha'a/tree and $0.06 \mathrm{~kg}$ Emselo/tree. In this season (2010), the average production of Edha'a amounted to $47.55 \mathrm{~kg} /$ person/season. In total, they harvested 11,887.5 kg Edha'a and $1600 \mathrm{~kg}$ 
Emselo during one season (average: 11 days) with the participation of 250 persons in the last season, which occurred 2.5 years ago. The average production of Edha'a amounted to $51 \mathrm{~kg} /$ person/season.

In the interview with the Socotra Women Development Association (SWDA), the price of $500 \mathrm{~g}$ (1 ratal) of dragon's blood started from 2.7 United States Dollar (USD) in 2003 and increased to 13.7 USD in 2010. Currently (2018), the price of dragon's blood resin (pure resin) has increased five times from the price in 2010 and reached $23 \mathrm{USD} / 500 \mathrm{~g}$.

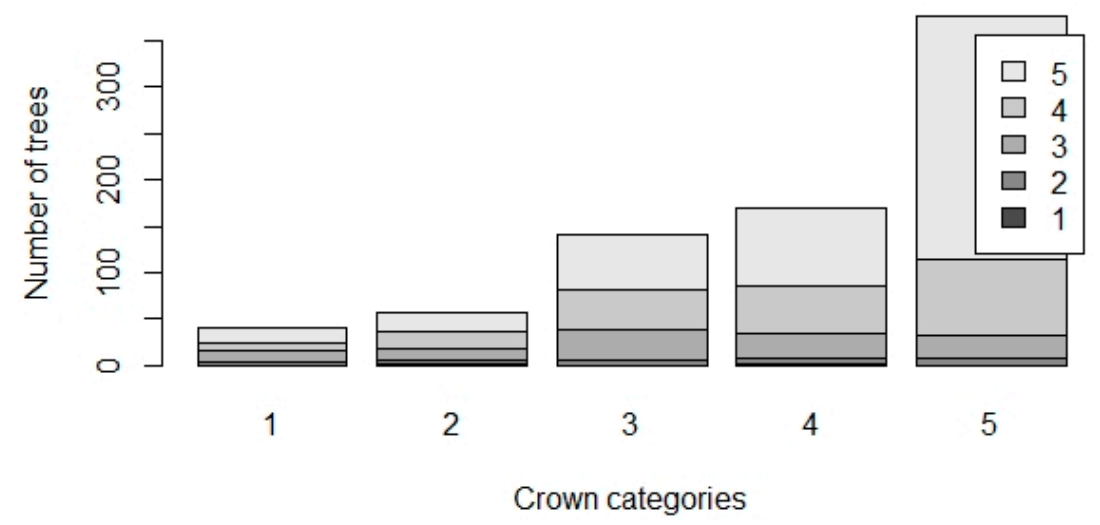

Figure 8. Barplot for the contingency table shows the relationship between the crown categories ( $x$-axis) and trunk categories (side colors with trunk categories; $p$-value $=8.632 \times 10^{-12}$; field measurements).

\section{Discussion}

\subsection{Population Structure}

Three vegetation strata can be identified that are dominated by D. cinnabari trees. Dracaena trees are characterized by different height and diameter classes, but they do not regenerate. Similarly, many authors have mentioned the lack of regeneration in dragon's blood tree forests and woodlands on Socotra [53,54]. Trees with heights of less than $2.9 \mathrm{~m}$ and diameters of less than $8 \mathrm{~cm}$ are absent, which supports the hypothesis of gradual extinction $[9,16]$ over the hypothesis of sudden mass extinction [10]. There is a sufficient number of Dracaena trees available, with an average cover of 67 trees $^{-1}{ }^{-1}$. Adolt et al. [14] published the results of dragon's blood tree population inventory in Firmihin; in an area of 648 ha, they estimated 65,509 living trees and 545 dead trees, with an average population density of 101 living trees ha ${ }^{-1}$. They also found an insufficient number of young trees and no or lack of regeneration. According to Adolt et al. [14], the mortality was less than 1\% (0.82\%), but this study showed four times higher mortality, reaching 3.41\%. Additionally, a study published by Maděra et al. [9] estimated that the mortality was less than $1 \%$, which differed substantially with the age of the trees. Despite the long-term morphological, anatomical, and physiological adaptations of the DC trees to arid climate conditions [22,28-30,32,55], the present tree populations do have an evidently unbalanced age structure with a largely disorganized woodland structure and a lack of natural regeneration [16].

In low-density areas, there is also a high density of harvested trees, which facilitates the degradation of D. cinnabari stands. This applies to other open areas, such as Dixam, Momi, Shibehon, Kilimo, and Sirahan. According to the inventory, there were 28 dead trees in 12 plots (12 ha), and the calculation showed that 36,300 (The number of trees in $550 \mathrm{ha}$ ) divided by 129 tree deaths each year means that the forest may be completely dead within 281 years. This estimation did not include any climatic or overmaturity scenarios, which could accelerate this mortality. Hubálková [12] and Habrová et al. [16] published predictive models of the future development at selected localities based on a detailed description of the stand structure by Habrová and Maděra [56] and the original methodology of the DC crown age estimation by Adolt and Pavliš [10] and Adolt et al. [13]. Authors have predicted that the DC abundance will decrease by $36 \%$, according to Hubálková [12], or 37\%, according to Habrová et al. [16], 
over the next 100 years, but both studies underestimated the mortality of dragon's blood trees in the oldest age classes in the population extinction models used by Maděra et al. [9].

\subsection{Population Decline due to Resin Harvesting}

The distribution of DC forests and woodlands was published by Král and Pavliš [39], who estimated the total area of habitats with the presence of DC at 7230 ha (6200 ha of DC woodlands, 230 ha of DC forests, and 800 ha of mountain forests with DC admixture). More precisely, using remotely sensed data, Madera et al. [9] estimated the total area of occupancy of the dragon's blood tree at 51,963 ha, which included 80,134 individuals (except the areas under 1100 masl). They also included habitats with individual DC tree occurrence. In the past, DC forests were presumably present over larger areas of the island [11,57]. According to Attorre et al. [11], DC occupies only 5\% of its current potential habitat. Conditionally, in a specific climate change scenario leading to increased aridity, the authors concluded that the current potential habitat of DC would be reduced by $45 \%$ by 2080 . Only two out of the nine remnant areas should be considered potential refugia [11].

Two hypotheses have been recently proposed to explain the recession of the DC communities. The first considered animal grazing the main driving force of the unsatisfactory tree regeneration and the prevailing absence of younger age classes [10]. The second hypothesis considers global climate change the main factor $[11,58]$. Regardless of the reason, DC forests and woodlands are threatened communities today $[37,59]$. Nobody has investigated the influence of dragon's blood harvesting on the population of such a threatened tree species, but we can expect that the large population decline was caused by unregulated overharvesting of resin in the past $[6,58]$.

According to the findings, dragon's blood harvesting negatively influences the population status. The measurement showed that $84 \%$ of trees were wounded, which was supported by local community interviews and field observations. According to the local communities, the wounds came naturally or were very old; currently, the local community does not make new wounds but harvests and often widens the old wounds. They make new wounds but accidentally or just for fun. The crown status was affected by the wounds on the trunk, as shown in Figure 7. Using analysis of variance (ANOVA) and the LSD test, the surface area of the wounds $\left(\mathrm{cm}^{2}\right)$ and its trunk status showed a positive correlation. This confirmed the fact that when the wounds on the trunk are extended by tapping, the trunk becomes more damaged. This causes a loss of stability due to the heavy crown and weak trunk and increases the likelihood that the trees will be blown over in the strong monsoon winds. Additionally, physiological processes (sap flow) can be affected [30].

\subsection{Harvesting Rules}

The harvesting rules are generally environmentally friendly and respect the trees. Nevertheless, the trees are damaged by tapping. According to the local leaders' responses, when the harvesting period is open, everyone can harvest but must respect the local rules. These rules are no longer written or announced in the meetings because they have been inherited with traditional knowledge.

The rules are summarized as follows:

1. Harvesting of dragon's blood resin should occur only during the period announced by community leaders.

2. A knife should be used for harvesting.

3. Do not damage the tree except the breaking of $2-3$ branches to enable entry into the crown (it is better to search for another tree rather than break the branches).

4. Do not use axes or stones for harvesting.

5. Do not make new wounds.

6. Do not hit the tree hard.

7. Do not cut as deep as the white bark.

8. Do not collect Edha'a (mixed resin) if you do not know how to do it. 
As shown by Figure 9 and the results of the questionnaire, the local community prefers harvesting from areas with a low number of trees. The linear model showed an increased percentage of used wounds with a decrease in the number of trees $\left(R^{2}=0.6103 ; p\right.$-value $\left.<0.05\right)$, and the results of the generalized linear mixed model (GLMM) described in Figure 10 showed that the probability of trees with used wounds increased with increasing DBH ( $p$-value $<0.05)$. As a result, the local people accelerate the deaths of mature trees with large diameters and do so for higher numbers of trees in populations with low density. The crowns of the trees showed a decrease in health with a greater number of wounds, as shown in Figure 7 by the multiple comparisons using the least significant difference (LSD) test and ANOVA with a $p$-value $<0.05$. From the observation and interviews with the local community, the trees in rocky areas had more wounds and produced more dragon blood tree resin. The tapping intensity increased in the areas that were easy to access, and that had higher productivity. According to the local community and compared to other areas in the highlands that do not produce dragon's blood tree resin, the sun's heat accelerates the production of dragon's blood tree resin. In Firmihin, there is still a high potential for harvesting since $69 \%$ of the trees are wounded but not actively harvested.

Sustained yields are secured by collecting Emselo (pure dragon's blood) or widening the wounds and damaging the trunk of the trees to collect Edha'a. Women, children, and reckless harvesters sometimes break the traditional rules and cause great damage to trees by using stones for harvesting. The amount of available Emselo is lower than that of Edha'a because the trees naturally produce very little Fosoos (pure resin), and harvesters carefully remove the pure slices from the wounds with knives. Edha'a is easily harvested because there is no need for skill to remove the resin without the bark, climb the tree, or clean the product mixed with the tree bark, so anyone can harvest Edha'a (mixed resin), including women and children.

Similar rules are followed by tappers of Boswellia papyrifera, who determine the harvesting season and number and position of tapping points according to the size of the tree [60,61], and by those who tap Boswellia sacra in Oman (but this traditional management knowledge is limited to the older generation) $[62,63]$. Sometimes the management of frankincense trees is shared between government authorities and local communities [64], and the effect of the tapping regime for frankincense harvesting can have negative impacts on the trees $[61,65,66]$. There is also traditional knowledge associated with the management of gum arabic in Kenya [67] and Sudan [68].

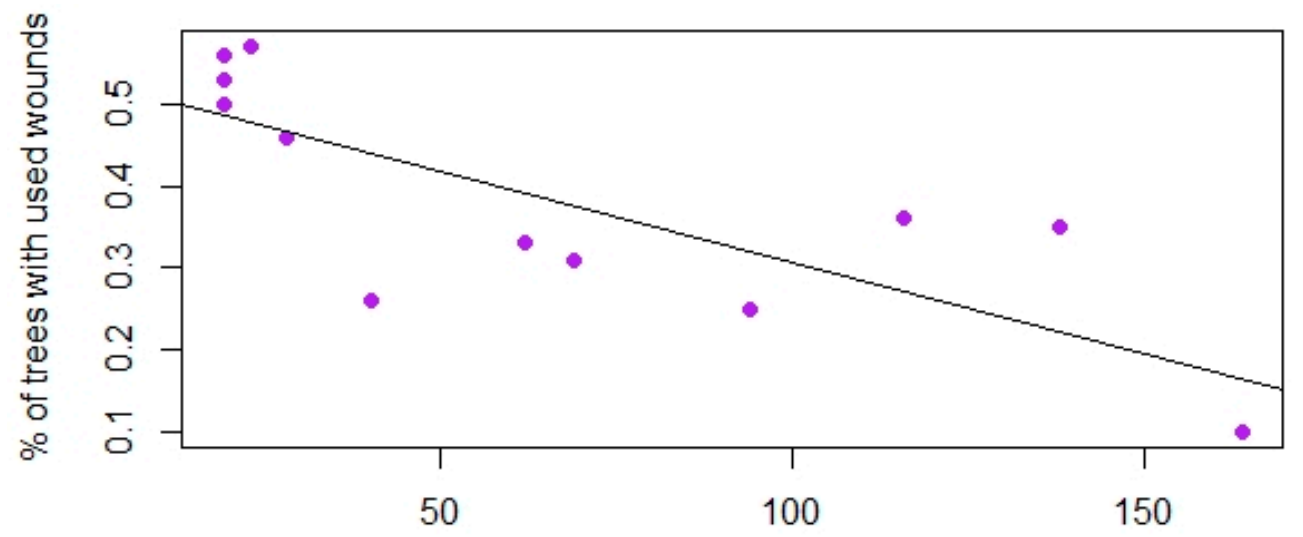

Number of trees per hectare

Figure 9. Correlation showing the relationship between the tree density and the percentage of trees with used wounds from the total wounded trees in 12 plots ( $p$-value $=0.002697$ ). 


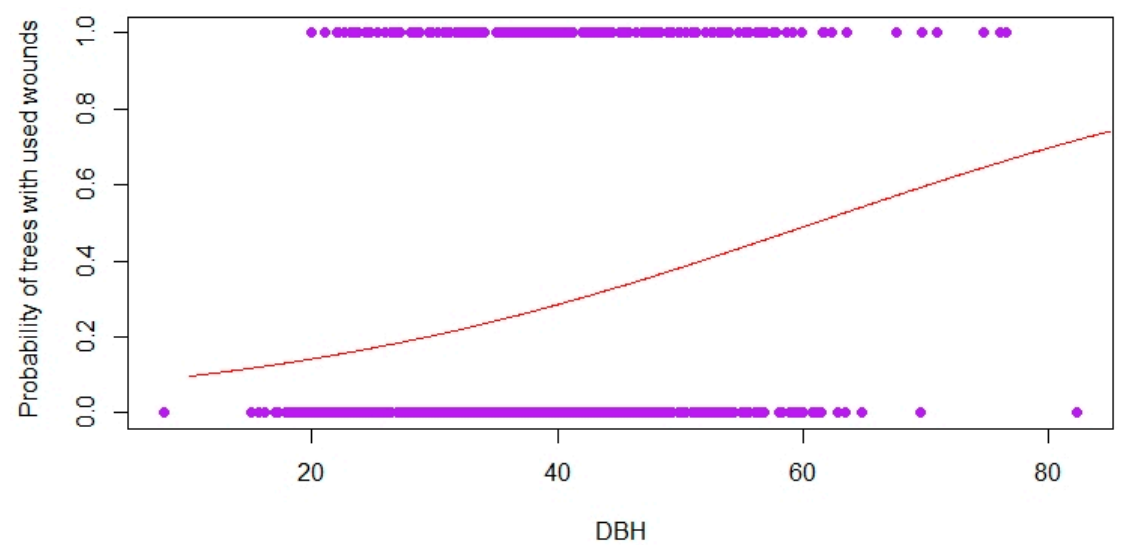

Figure 10. Correlation showing the relationship between diameter at breast height (DBH) and the probability of trees having used wounds (209 trees) out of the total wounded trees (667 trees; $p$-value $=1.34 \times 10^{-6}$; field measurements).

\subsection{The Economy of Dragon's Blood}

There has been an obvious increase in the price of dragon's blood tree resin during the last 10 years. The increase in price is associated with a larger demand from tourism activities. Edha'a and Emselo are sold to wholesalers who offer it to national traders in Aden (on the south coast of Yemen). According to the wholesaler, he simply acts as a representative of a national trader in Aden and gets $5 \%$ of the overall income. The national traders reexport the product to national and international markets. Collecting dragon's blood tree resin is the third source of income for the local community in the study area after pastures and palm cultivation. Despite the current war, the price of dragon's blood resin has increased, and the market is still continuing by export, mainly to mainland Yemen. Nevertheless, the local communities are not reinvesting a part of the income into forest regeneration, and the harvesting strategy is not in compliance with the principles of sustainable management.

The important NTFPs in international markets include gum luban or olibanum from Boswellia papyrifirea in Sudan, which generated USD 172,000 in 2007 alone [69] and increased to USD 4.5 million in 2018 [70]. Sometimes the change in the production and price is affected by a change in policies. Tourism also has positive impacts on other types of resin production, such as the prepackaging of small incense burners and some incense for tourists in Oman [62]. Wholesalers, especially assemblers, have an important role in gum and resin value chains [71].

\section{Conclusions}

The Firimhin forest is still healthy, and the D. cinnabari community still has a good structure. The harvesting of dragon blood tree resin is still completely managed by the local community.

There are some traditional management rules for harvesting dragon's blood tree resin, and the people still respect their local leaders. Harvesting is open for everyone, and there has been an increase in "guest harvesters" who are not aware of and do not respect the local rules, so these rules will become less effective, and harvesting will become increasingly difficult to control. The local management system of dragon's blood tree resin is not sustainable and requires some revisions. The main weakness of traditional management is that Edha'a is harvested by damaging the trunk and widening the wounds and that there are unclear rules and ineffective control of harvesting. The increase in tourism has had an indirect negative impact by creating a higher demand but could also have a positive impact by shifting production towards Emselo, which is less harmful to trees and more preferred by tourists (pure dragon's blood).

Community-based management plans, laws, and legislation focusing on harvesting Emselo and prohibiting the harvesting of Edha'a can be one method for sustainable management. International tools such as fair trading and the carbon market could be additional management alternatives. 
Dragon's blood tree resin is an important product for the local communities in the study area. The study shows that this source of income will disappear with the decreasing number of trees and the lack of natural regeneration. The production of dragon's blood tree resin is based on old wounds. However, the demand for resin is increasing, especially in the local market, in relation to the increasing number of tourists. Beyond the local market, there is also a high potential for developing the national and international markets. The creation of value-adding products has a high potential for improving prices. Selling dragon's blood tree resin in nice packages with informational labels will increase its value, as already demonstrated by the SWDA, which sells dragon's blood tree resin as souvenirs for tourists.

An understanding of forest characteristics and local management of dragon's blood tree resin is necessary to enable sustainable natural resource management and wise decision making. Further studies on dragon's blood tree harvesting and management, its possible impacts on the forest, assessment of local management systems, and the collection of data to address the information gap about $D$. cinnabari management are required.

Acknowledgments: I would like to thank Abdul Rahman Fadhl Al-Eryani for supporting my field work. Special thanks to Petr Maděra for his wholehearted scientific guidance, encouragement, and support during the design, data analysis, and write-up phases. I am also grateful for Jindřich Pavliš, Hana Habrova, Karel Drapela, and Daniel Volarik from Mendel University in Brno for their support and to the Environmental Protection Authority Socotra for their valuable support. My thanks to Hubertus Pohris and Klaus Römisch at the Technical University Dresden for their support during my master study. My great thanks is extended to Lisa Banfield for reviewing my writing and, overall, to the people of Socotra.

Funding: This study was undertaken as part of my master's thesis at the Technical University of Dresden, Germany, the fieldwork was financed by the DAAD German cooperation and partly supported by the Ministry of Water and Environment, Yemen.

Conflicts of Interest: The authors declare that they have no conflicts of interest.

\section{References}

1. Richards, M. The Potential of Non-Timber Forest Products in Sustainable Natural Forest Management in Amazonia. Commonw. For. Rev. 1993, 72, 21-27.

2. Ruiz Perez, M.; Ndoye, O.; Eyebe, A.; Puntodewo, A. Spatial Characterisation of Non-Timber Forest Products Markets in the Humid Forest Zone of Cameroon. Int. For. Rev. 2000, 2, 71-83.

3. UNCTAD. Commodities at a Glance: Special Issue on Gum Arabic. In United Nations Conference on Trade and Development; UNCTAD: Geneva, Switzerland, 2018; Vol. Issue No.8.

4. Fleurentin, J.; Mazars, G.; Pelt, J.-M. Cultural background of the medicinal plants of Yemen. J. Ethnopharmacol. 1983, 7, 183-203. [CrossRef]

5. Maděra, P.; Paschová, Z.; Ansorgová, A.; Vrškový, B.; Lvončík, S.; Habrová, H. Volatile Compounds in Oleo-gum Resin of Socotran Species of Burseraceae. Acta Univ. Agric. Silvic. Mendel. Brun. 2017, 65, 73-90. [CrossRef]

6. Miller, A.G.; Morris, M. Ethnoflora of the Soqotra Archipelago; Royal Botanic Garden Edinburgh: Edinburgh, UK, 2004.

7. Brown, G.; Mies, B.A. Vegetation Ecology of Socotra; Springer Science and Business Media: Berlin/Heidelberg, Germany, 2012; Volume 7.

8. Rejzek, M.; Svatek, M.; Šebesta, J.; Adolt, R.; Madera, P.; Matula, R. Loss of a single tree species will lead to an overall decline in plant diversity: Effect of Dracaena cinnabari Balf. f. on the vegetation of Socotra Island. Boil. Conserv. 2016, 196, 165-172. [CrossRef]

9. Maděra, P.; Volařík, D.; Patočka, Z.; Kalivodová, H.; Divín, J.; Rejžek, M.; Vybíral, J.; Lvončík, S.; Jeník, D.; Hanáček, P.; et al. Sustainable Land Use Management Needed to Conserve the Dragon's Blood Tree of Socotra Island, a Vulnerable Endemic Umbrella Species. Sustainability 2019, 11, 3557. [CrossRef]

10. Adolt, R.; Pavlis, J. Age structure and growth of Dracaena cinnabari populations on Socotra. Trees 2004, 18, 43-53. [CrossRef] 
11. Attorre, F.; Francesconi, F.; Taleb, N.; Scholte, P.; Saed, A.; Alfó, M.; Bruno, F. Will dragonblood survive the next period of climate change? Current and future potential distribution of Dracaena cinnabari (Socotra, Yemen). Boil. Conserv. 2007, 138, 430-439. [CrossRef]

12. Hubálková, I. Prediction of Dragon's Blood Tree (Dracaena cinnabari Balf.) Stand Sample Density on Soqotra Island. J. Landsc. Ecol. 2011, 4, 5-17. [CrossRef]

13. Adolt, R.; Habrová, H.; Maděra, P. Crown age estimation of a monocotyledonous tree species Dracaena cinnabari using logistic regression. Trees 2012, 26, 1287-1298. [CrossRef]

14. Adolt, R.; Maděra, P.; Abraham, J.; Čupa, P.; Svatek, M.; Matula, R.; Šebesta, J.; Čermák, M.; Volařík, D.; Koutecký, T.; et al. Field Survey of Dracaena Cinnabari Populations in Firmihin, Socotra Island: Methodology and Preliminary Results. J. Landsc. Ecol. 2013, 6, 7-34. [CrossRef]

15. Habrová, H.; Buček, A. Overview of Biotope Types of Socotra Island. J. Landsc. Ecol. 2013, 6, 60-83. [CrossRef]

16. Habrová, H.; Cermak, Z.; Pavlis, J. Dragon's blood tree-Threatened by overmaturity, not by extinction: Dynamics of a Dracaena cinnabari woodland in the mountains of Soqotra. Boil. Conserv. 2009, 142, 772-778. [CrossRef]

17. Carlquist, S. Monocot Xylem Revisited: New Information, New Paradigms. Bot. Rev. 2012, 78, 87-153. [CrossRef]

18. Rudall, P. Lateral meristems and stem thickening growth in monocotyledons. Bot. Rev. 1991, 57, $150-163$. [CrossRef]

19. Jura-Morawiec, J.; Tulik, M.; Iqbal, M. Lateral Meristems Responsible for Secondary Growth of the Monocotyledons: A Survey of the State of the Art. Bot. Rev. 2015, 81, 150-161. [CrossRef] [PubMed]

20. Jura-Morawiec, J. Atypical origin, structure and arrangement of secondary tracheary elements in the stem of the monocotyledonous dragon tree, Dracaena draco. Planta 2016, 245, 93-99. [CrossRef]

21. Jura-Morawiec, J.; Wiland-Szymańska, J. A novel insight into the structure of amphivasal secondary bundles on the example of Dracaena draco L. stem. Trees 2014, 28, 871-877. [CrossRef]

22. Klimko, M.; Wiland-Szymanska, J. Scanning Electron Microscopic Studies of Leaf Surface in Taxa of Genus Dracaena L. (Dracaenaceae). Rocz. Akad. Rol. W Pozn. Bot.-Steciana 2008, 12, 117-127.

23. Jupa, R.; Plichta, R.; Paschová, Z.; Nadezhdina, N.; Gebauer, R. Mechanisms underlying the long-term survival of the monocot Dracaena marginata under drought conditions. Tree Physiol. 2017, 37, 1182-1197. [CrossRef]

24. Cui, J.-L.; Wang, C.-L.; Guo, S.; Xiao, P.-G.; Wang, M. Stimulation of dragon's blood accumulation in Dracaena cambodiana via fungal inoculation. Fitoterapia 2013, 87, 31-36. [CrossRef] [PubMed]

25. Fan, L.-L.; Tu, P.-F.; He, J.-X.; Chen, H.-B.; Cai, S.-Q. Microscopical Study of Original Plant of Chinese Drug "Dragon's Blood" Dracaena cochinchinensis and Distribution and Constituents Detection of Its Resin. China J. Chin. Mater. Medica 2008, 33, 1112-1117.

26. Gonzalez, A.G.; Hernández, J.C.; León, F.; Padrón, J.I.; Estévez, F.; Quintana, J.; Bermejo, J. Steroidal Saponins from the Bark of Dracaenadraco and Their Cytotoxic Activities. J. Nat. Prod. 2003, 66, 793-798. [CrossRef] [PubMed]

27. Wang, X.-H.; Zhang, C.; Yang, L.-L.; Gomes-Laranjo, J. Production of dragon's blood in Dracaena cochinchinensis plants by inoculation of Fusarium proliferatum. Plant Sci. 2011, 180, 292-299. [CrossRef]

28. Jura-Morawiec, J.; Tulik, M. Morpho-anatomical basis of dragon's blood secretion in Dracaena draco stem. Flora-Morphol. Distrib. Funct. Ecol. Plants 2015, 213, 1-5. [CrossRef]

29. Nadezhdina, N.; Nadezhdin, V. Are Dracaena nebulophytes Able to Drink Atmospheric Water? Environ. Exp. Bot. 2017, 139, 57-66. [CrossRef]

30. Nadezhdina, N.; Al-Okaishi, A.; Maděra, P. Sap Flow Measurements in a Socotra Dragon's Blood Tree (Dracaena cinnabari) in its Area of Origin. Trop. Plant Boil. 2018, 11, 107-118. [CrossRef]

31. Nadezhdina, N.; Gebauer, R.; Nadezhdin, V.; Plichta, R. Water transport secrets of the dragon's blood trees revealed through sap flow measurements following partial stem incision. Flora-Morphol. Distrib. Funct. Ecol. Plants 2019, 250, 44-51. [CrossRef]

32. Nadezhdina, N.; Plichta, R.; Nadezhdin, V.; Gebauer, R.; Jupa, R.; Habrová, H.; Maděra, P. A comparative structural and functional study of leaf traits and sap flow in Dracaena cinnabari and Dracaena draco seedlings. Funct. Plant Boil. 2015, 42, 1092-1105. [CrossRef]

33. Mayer, A.-N. Probleme Touristischer Entwicklung auf der Insel Soqotra: Vom Missverständnis "Ökotourismus" zu Nachhaltigem Tourismus? Reichert: Wiesbaden, Germany, 2009; Jemen Studien 19, pp. 1-152. 
34. Breasted, J.H.; Schoff, W.H. The Periplus of the Erythraean Sea: Travel and Trade in the Indian Ocean by a Merchant of the First Century. Am. Hist. Rev. 1912, 18, 118-120. [CrossRef]

35. Lucas, G.; Synge, H. The IUCN Plant Red Data Book; IUCN: Morges, Switzerland, 1978; pp. 193-194.

36. Culek, M. Geological and Morphological Evolution of the Socotra Archipelago (Yemen) from the Biogeographical View. J. Landsc. Ecol. 2013, 6, 84-108. [CrossRef]

37. Scholte, P.; De Geest, P. The climate of Socotra Island (Yemen): A first-time assessment of the timing of the monsoon wind reversal and its influence on precipitation and vegetation patterns. J. Arid. Environ. 2010, 74, 1507-1515. [CrossRef]

38. Culek, M.; Kral, K.; Habrova, H.; Adolt, R.; Pavliš, J.; Maděra, P. Socotra's Annual Weather Pattern. In Socotra: A Natural History of the Islands and Their People; Odyssey Books \& Guides: Hone Kong, China, 2006; pp. 62-65.

39. Král, K.; Pavlis, J. The first detailed land-cover map of Socotra Island by Landsat/ETM+ data. Int. J. Remote. Sens. 2006, 27, 3239-3250. [CrossRef]

40. Ndangalasi, H.J.; Bitariho, R.; Dovie, D.B.K. Harvesting of non-timber forest products and implications for conservation in two montane forests of East Africa. Boil. Conserv. 2007, 134, 242-250. [CrossRef]

41. Arnold, J.E.M.; Ruiz Pérez, M. The Role of Non-Timber Forest Products in Conservation and Development. In Incomes from the Forest: Methods for the Development and Conservation of Forest Products for Local Communities; CIFOR: Bogor, Indonesia, 1998; pp. 17-42.

42. Arnold, J.; Pérez, M. Can non-timber forest products match tropical forest conservation and development objectives? Ecol. Econ. 2001, 39, 437-447. [CrossRef]

43. Coppen, J.J.W. Non-Wood Forest Products: 6-Gums, Resins and Latexes of Plant Origin; FAO: Rome, Italy, 1995.

44. FAO. Non-Wood Forest Products: 7-Non-Wood Forest Products for Rural Income and Sustainable Forestry; FAO: Rome, Italy, 1995.

45. Ojha, H.; Subedi, B.; Dangol, S. Assessment of Sustainable Harvesting of Non-Timber Forest Products: Some Initiatives in Community Forestry in the Hills of Nepal; ANSAB: Kathmandu, Nepal, 2001.

46. Peres, C.A.; Lake, I.R. Extent of Non-timber Resource Extraction in Tropical Forests: Accessibility to Game Vertebrates by Hunters in the Amazon Basin. Conserv. Biol. 2003, 17, 521-535. [CrossRef]

47. Khanal, M. Non-Timber Forest Products (NTFPs): Use in Two Villages in Lumbini Zone of Nepal. Master's Thesis, University of Natural Resources and Applied Life Sciences, Vienna, Austria, 2006.

48. Singh, K.D. Global Forest Resources Assessments. In Capacity Building for the Planning, Assessment and Systematic Observations of Forests; Springer: Berlin/Heidelberg, Germany, 2013; pp. 203-211. [CrossRef]

49. Kaplinsky, R.; Morris, M. A Handbook for Value Chain Research; University of Sussex, Institute of Development Studies: Brighton, UK, 2000; Volume 113.

50. Subramanian, U. Moving toward Competitiveness: A Value Chain Approach; The World Bank: Columbia, DC, USA, 2007.

51. Ostrom, E.; Gardner, R.; Walker, J. Rules, Games, and Common-Pool Resources; University of Michigan Library: Ann Arbor, MI, USA, 1994.

52. Van Noordwijk, M.; Purnomo, H.; Peskett, L.; Setiono, B. Reducing Emissions from Deforestation and Forest Degradation (REDD) in Indonesia: Options and Challenges for Fair and Efficient Payment Distribution Mechanisms; ICRAF Working Paper No. 81; World Agroforestry Centre-ICRAF Southeast Asia Regional Office: Bogor, Indonesia, 2008; Volume 29.

53. Hubálková, I.; Maděra, P.; Volařík, D. Growth dynamics of Dracaena cinnabari under controlled conditions as the most effective way to protect endangered species. Saudi J. Boil. Sci. 2015, 24, 1445-1452. [CrossRef]

54. Maděra, P.; Habrová, H.; Šenfeldr, M.; Kholová, I.; Lvončík, S.; Ehrenbergerová, L.; Roth, M.; Nadezhdina, N.; Němec, P.; Rosenthal, J.; et al. Growth dynamics of endemic Dracaena cinnabari Balf. f. of Socotra Island suggest essential elements for a conservation strategy. Boilogia 2018, 74, 339-349. [CrossRef]

55. Krawczyszyn, J.; Krawczyszyn, T. Massive aerial roots affect growth and form of Dracaena draco. Trees 2014, 28, 757-768. [CrossRef]

56. Habrová, H.; Maděra, P. Ecology of Dragon's blood tree (Dracaena cinnabari) Communities on Socotra Island. In Evaluation of State and Development of Forest Geobiocoenosis; Faculty of Forestry and Wood, Technology, Polehla, P., Eds.; Mendel University: Brno, Czech Republic, 2004.

57. Habrová, H. Geobiocoenological Differentiation as a Tool for Sustainable Land-Use of Socotra Island. Ecology 2004, 23, 47-57. 
58. Miller, A.; Morris, M. Conservation and Sustainable Use of the Biodiversity of the Soqotra Archipelago; Final Report (Botany), YEM/96/G32; Royal Botanic Garden: Edinburgh, UK, 2001.

59. Scholte, P.; Al-Okaishi, A.; Suleyman, A.S. When conservation precedes development: A case study of the opening up of the Socotra archipelago, Yemen. Oryx 2011, 45, 401-410. [CrossRef]

60. Ogbazghi, W. The Distribution and Regeneration of Boswellia Papyrifera (Del.) Hochst. Ph.D. Thesis, Wageningen University \& Research, Wageningen, The Netherlands, 2001.

61. Ali, A.H.; Fadl, K.E.M.; Adam, I.M. Effect of Position of Tapping, Tree Stem Diameter and Tapping Tools on Frankincense Yield of Boswellia Papyrifera in South Kordofan State, Sudan. For. Trees Livelihoods 2009, 19, 19-26. [CrossRef]

62. Farah, M. Non-Timber Forest Product (NTFP) Extraction in Arid Environments: Land-Use Change, Frankincense Production and the Sustainability of Boswellia Sacra in Dhofar (Oman); The University of Arizona: Tucson, AZ, USA, 2008.

63. Alaamri, M.M.H. Distribution Boswellia sacra in Dhofar Mountains, Sultanate of Oman: Economic Value And. J. Life Sci. 2012, 6, 632-636.

64. Tilahun, M.; Olschewski, R.; Kleinn, C.; Gebrehiwot, K. Economic analysis of closing degraded Boswellia papyrifera dry forest from human interventions-A study from Tigray, Northern Ethiopia. For. Policy Econ. 2007, 9, 996-1005. [CrossRef]

65. Rijkers, T.; Ogbazghi, W.; Wessel, M.; Bongers, F. The effect of tapping for frankincense on sexual reproduction in Boswellia papyrifera. J. Appl. Ecol. 2006, 43, 1188-1195. [CrossRef]

66. Eshete, A. The Frankincense Tree of Ethiopia Ecology, Productivity and Population Dynamics; Wageningen University: Wageningen, The Netherlands, 2011.

67. Wekesa, C.; Makenzi, P.M.; Chikamai, B.N.; Luvanda, A.M.; Muga, O.M. Traditional ecological knowledge associated with Acacia senegal (Gum arabic tree) management and gum arabic production in northern Kenya. Int. For. Rev. 2010, 12, 240-246.

68. Adam, H.E.; Eltahir, M.E.; Elhaja, M.E.; Ibrahim, A.H.; Abdelkareem, O.E.; Hammad, Z.M.; Khalifa, A.S.; Mahmoud, T.E.; Elsayed, M.E.; Elamin, H.M. Management of Gum Arabic Production Potentialities in the Gum Belt in Kordofan, Sudan. Int. J. Environ. Plan. Manag. 2017, 3, 1-9.

69. Annual Report 2007 | CBOS /En/Content/Annual-Report-2007. Available online https://cbos.gov.sd/sites/ default/files/annual07_0.pdf (accessed on 17 November 2019).

70. 4th Quarter 2018 | CBOS /En/Content/4th-Quarter-2018. Available online https://cbos.gov.sd/sites/default/ files/digest-q4-2018.pdf (accessed on 17 November 2019).

71. Kassa, H.; Tefera, B.; Fitwi, G. Preliminary Value Chain Analysis of Gum and Resin Marketing in Ethiopia; Center for International Forestry Research (CIFOR): Bogor, Indonesia, 2011. 